\title{
Effect of Laser Peening on Improving Fatigue Strength of Welded Rib of High-Strength Steel*
}

\author{
by SAKINO Yoshihiro**, YOSHIKAWA Kenichi***, SANO Yuji**** and SUMIYA Rie*****
}

\begin{abstract}
Laser peening can introduce compressive residual stress to the surface and, therefore, is effective in enhancing the fatigue strength. This study targets $780 \mathrm{MPa}$ grade high-strength steel (HT780) in order to clarify whether laser peening generates compressive residual stress on the surface of HT780, and whether such stress would account for prolonged fatigue life in the welded zones of HT780. As a result, large and deep compressive residual stress was generated on the base metal surface and at the boxing toe of HT780 under the peening conditions employed for $490 \mathrm{MPa}$ grade steel. The smaller the applied stress range, the greater was the improvement of the fatigue life of the high-strength steel boxing toe by laser peening.
\end{abstract}

Key Words: Laser peening, High-strength steel, Fatigue strength, Box welded joint, Residual stress

\section{Introduction}

In recent times, increase in the size of steel structures has led to an increased demand for lighter steel structure; this demand has been satisfied through the use of high-strength steel with tensile strengths exceeding $570 \mathrm{MPa}$ in welded structures such as penstocks and long-span bridges. Compared to mild steel, highstrength steels not only facilitate the building of lighter structures through the reduction in plate thickness, but also are reduce manhours required for welding and save materials. Therefore, highstrength steel plays a significant role in large structures. However, high stress concentration at the toe or other welded zones of the structure often results in fatigue cracking. This stress concentration is known to significantly depend on shape but not on the strength of the base metal. This indicates that although tensile strength of high-strength steel is higher than that of mild steel, the fatigue strength of a welded structure employing highstrength steel does not differ greatly from that of a welded structure of mild steel. Thus, the fatigue strength at the welded part substantially reduces the advantage of using high-strength steel.

Of the various methods employed for improving the fatigue strength of a welded zone, the authors have focused on laser peening ${ }^{1)}$. Laser peening is effective for preventing the initiation and propagation of stress corrosion cracking (SCC) and has been

\footnotetext{
*受付日 平成27年 7 月 10 日 受理日 平成27年12月22日 平成21年11月溶接構造シンポジウムで発表

**正 員 近畿大学工学部 Member, Kinki University Faculty of Engineering

*** 元：大阪大学大学院 Graduate School of Engineering Osaka University

*****東芝電力システム社 Toshiba Corporation

*****正 現所属 : 科学技術振興機構

*****正 員 東芝電力システム社 Member, Toshiba Corporation
}

applied to operating nuclear power reactors ${ }^{2)}$.

Recent studies have revealed that laser peening dramatically improves the fatigue properties of austenitic stainless steels ${ }^{3)}$, aluminum alloys ${ }^{4)}$, and titanium alloys ${ }^{5}$. However, there is no open literature on the application of laser peening to huge structures such as bridges, other than the work of the authors. The fatigue life of bridges is decreasing significantly because of heavy traffic $^{6}$, and thus, it is necessary to reduce the welding residual stresses in bridge members. However, stress relief heat treatments ${ }^{7)}$ are not applicable to such big structures. Therefore, measures for reducing welding residual stresses in large welded structures that do not deteriorate the strength of the welded members are wanted. Laser peening is considered to be one of the most promising processes.

The authors studied laser peening conditions for structural steels by measuring the residual stress and performing hardness tests $^{8)}$. Then, they also studied changes in the surface residual stress, the depth distribution of residual stress, the hardness distribution, and the surface roughness in four types of structural steel with different strengths and in the welded zone ${ }^{9)}$. Moreover, it is clarified that the fatigue life of the welded joints is substantially extended by laser peening ${ }^{10,11)}$ and the generation of compressive residual stress by laser peening is the major factor improving the fatigue life ${ }^{12)}$.

This study targets high-strength steel (HT780) in order to clarify whether laser peening generates compressive residual stress on the surface of HT780, and whether such stress would account for prolonged fatigue life in the welded zones of HT780.

\section{Change of residual stress by laser peening}

The residual stresses of the laser-peened base metal and the laser-peened boxing toe of the welded rib plate of HT780 were measured to determine whether laser peening generated 
compressive residual stresses on the surface. The measured values were compared with the residual stresses on an unpeened specimen in order to identify the change of residual stresses by laser peening.

\section{Residual stress in base metal}

For two different production rots of the $9 \mathrm{~mm}$ thick highstrength steel (HT780-1 and HT780-2), the surface residual stresses were measured at the laser-peened spots and at the unpeened spots. Tables 1 and 2 list the mechanical properties and chemical compositions of the two steels.

Laser peening of the HT780s was performed under the same conditions as those applied for the peening of $490 \mathrm{MPa}$ grade steel (SM490). Pulse energy is $200 \mathrm{~mJ}$, spot diameter is $0.8 \mathrm{~mm}$, and irradiation density is 36 pulse $/ \mathrm{mm}^{2}$ ). The pitch of the pulse laser was $1 / 60 \mathrm{~mm}$, and the stage with the specimen placed on it was moved. After the stage was moved by $10 \mathrm{~mm}$, the process was reversed in order to have a line $1 / 60 \mathrm{~mm}$ below the previous irradiated line. The repetition of this process resulted in the irradiation of an area of $10 \times 10 \mathrm{~mm}$. The residual stress at center of irradiation area was measured by X-ray diffraction (XRD, the $\sin ^{2} \psi$ method, collimator diameter: $\left.2 \mathrm{~mm}\right)$ using $\mathrm{Cr}-\mathrm{K} \alpha(17 \mathrm{kV}$, $2.0 \mathrm{~mA}$ ) as the X-ray source.

Table 3 lists the measurement results, where the values are the mean of the two spots. $\sigma_{\mathrm{x}}$ represents the residual stress

Table 1 Mechanical properties

\begin{tabular}{lllll}
\hline & \multicolumn{4}{l}{ Mechanical properties } \\
\cline { 2 - 5 } & $\sigma_{\mathrm{Y}}$ & $\sigma_{\mathrm{U}}$ & $\delta$ & $\mathrm{YR}$ \\
& $(\mathrm{MPa})$ & $(\mathrm{MPa})$ & $(\%)$ & $(\%)$ \\
\hline HT780-1 & 789 & 842 & 19 & 94 \\
HT780-2 & 804 & 823 & 21 & 95 \\
Welding wire* & 710 & 830 & 24 & - \\
\hline *: catalogue value
\end{tabular}

Table 2 Chemical compositions

\begin{tabular}{|c|c|c|c|c|c|c|c|c|c|c|c|}
\hline & \multicolumn{11}{|c|}{ Chemical composition (\%) } \\
\hline & $\mathrm{C}$ & $\mathrm{Si}$ & $\mathrm{Mn}$ & $\mathrm{P}$ & $\underline{\mathrm{S}}$ & $\mathrm{Cu}$ & $\mathrm{Ni}$ & $\mathrm{Cr}$ & Mo & $\mathrm{V}$ & $\mathrm{B}$ \\
\hline & \multicolumn{2}{|c|}{$\times 10^{-2}$} & \multicolumn{2}{|c|}{$\times 10^{-3}$} & \multicolumn{3}{|c|}{$\times 10^{-2}$} & \multicolumn{4}{|c|}{$\times 10^{-3}$} \\
\hline HT780-1 & 19 & 23 & 145 & 9 & 1 & - & - & - & - & - & 1 \\
\hline HT780-2 & 15 & 36 & 120 & 12 & 1 & 1 & 1 & 10 & 12 & 0 & 1 \\
\hline Welding wire* & 8 & 38 & 125 & 9 & 11 & - & 222 & - & 63 & - & - \\
\hline
\end{tabular}

Table 3 Results of residual stress measurement

\begin{tabular}{|c|c|c|c|c|c|c|}
\hline & \multicolumn{6}{|c|}{ Residual stress (MPa) } \\
\hline & \multicolumn{2}{|c|}{$\begin{array}{l}\text { Without } \\
\text { laser peening }\end{array}$} & \multicolumn{2}{|c|}{$\begin{array}{l}\text { With } \\
\text { laser peening }\end{array}$} & \multicolumn{2}{|c|}{$\begin{array}{l}\text { Change by } \\
\text { laser peening }\end{array}$} \\
\hline & $\sigma_{\mathrm{x}}$ & $\sigma_{\mathrm{y}}$ & $\sigma_{\mathrm{x}}$ & $\sigma_{\mathrm{y}}$ & $\sigma_{\mathrm{x}}$ & $\sigma_{\mathrm{y}}$ \\
\hline HT780-1 & $-44 \pm 18$ & $-35 \pm 30$ & $-174 \pm 6$ & $-312 \pm 8$ & -131 & -278 \\
\hline HT780-2 & $-6 \pm 13$ & $-70 \pm 7$ & $-191 \pm 3$ & $-330 \pm 6$ & -185 & -260 \\
\hline
\end{tabular}

component in the direction of the stage movement, while $\sigma_{\mathrm{y}}$ is the component perpendicular to this direction.

In Table 3, the most probable values calculated through the $\sin ^{2} \psi$ method are listed with the confidence intervals $(1 \sigma)$ after the \pm symbols. The confidence interval has $\pm 30 \mathrm{MPa}$ at maximum but is mostly around $\pm 10 \mathrm{MPa}$. The spots that were not laser peened have compressive residual stresses around -6 to $-70 \mathrm{MPa}$ for $\sigma_{\mathrm{x}}$ and $\sigma_{\mathrm{y}}$, respectively. This stress was probably generated during the cooling of the manufacturing process for the steel plate. As for the laser peened spots, significant compressive residual stresses around -170 to -190 MPa were generated for $\sigma_{\mathrm{x}}$, and -300 to $-330 \mathrm{MPa}$ for $\sigma_{\mathrm{y}}$. Comparing the residual stress components $\sigma_{\mathrm{x}}$ and $\sigma_{\mathrm{y}}$, the former tends to result in greater compressive residual stress. This phenomenon is also seen in other materials after laser peening and needs further investigation. The difference between the laser peened and unpeened spots is around $150 \mathrm{MPa}$ at $\sigma_{\mathrm{x}}$ and about $270 \mathrm{MPa}$ at $\sigma_{\mathrm{y}}$, showing a significant change in residual stress towards the compressed side. These values confirm that the base metal in high-strength steel generates large compressive residual stress on the surface when the peening conditions employed for SM490 are applied for the high-strength steel.

\section{Surface residual stress in boxing toe}

Figure 1 shows the shape and dimensions of the specimen, in which an all-round fillet (one-pass, measured leg length: $7 \mathrm{~mm}$ ) is welded to a $9 \mathrm{~mm}$ thick steel plate HT780-2, along with a $6 \mathrm{~mm}$ thick steel plate used as a rib. The $6 \mathrm{~mm}$ thick steel plate is obtained by reducing the thickness of HT780-2 and groove was not prepared. $\mathrm{CO}_{2}$ arc welding was employed and solid wire for the $780 \mathrm{MPa}$ grade steel was used as the welding material. Table 1 and 2 list the catalogue values for the mechanical properties and

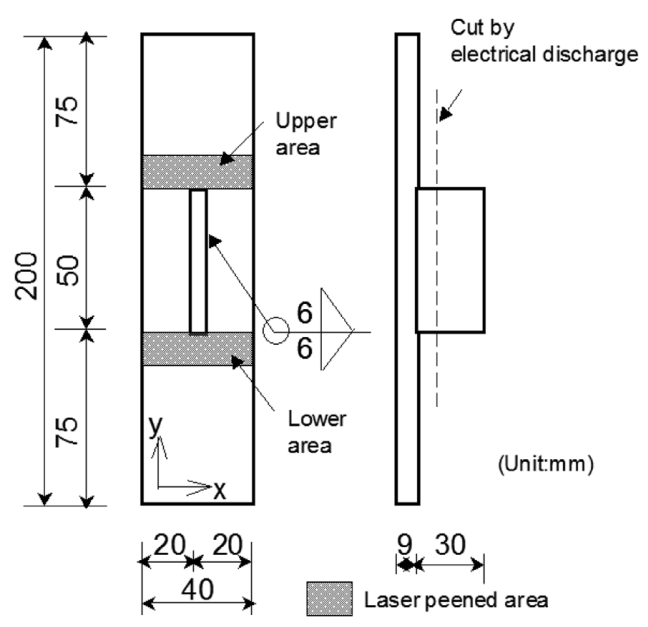

Fig. 1 Specimen for residual stress measurement 
chemical compositions of the wire. The welding voltage, the welding current and the welding speed were 25-27 V, 200-210 A and about $180 \mathrm{~mm} / \mathrm{min}$, respectively. The rib-plate was cut by electrical discharge at a height of $8 \mathrm{~mm}$, because the rib-plate disturbed residual stress measurement of a Y-direction stress component $\left(\sigma_{\mathrm{y}}\right)$ by XRD.

First, the residual stresses near the upper and lower boxing toes were measured. Then an area of $40 \times 20 \mathrm{~mm}$ around the boxing toes was laser-peened and residual stresses at the same positions

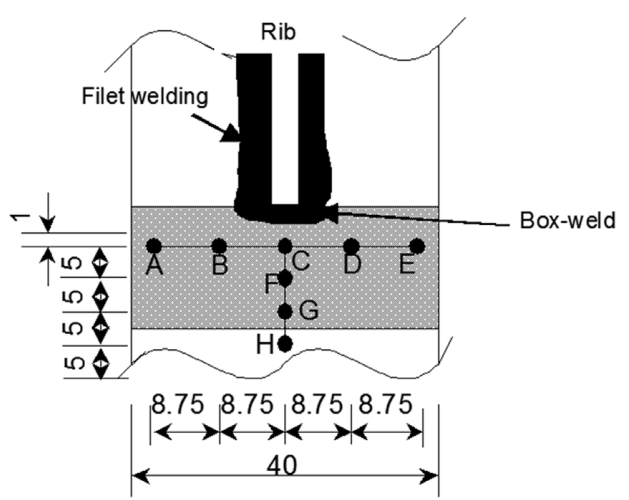

Fig. 2 Measuring points of XRD

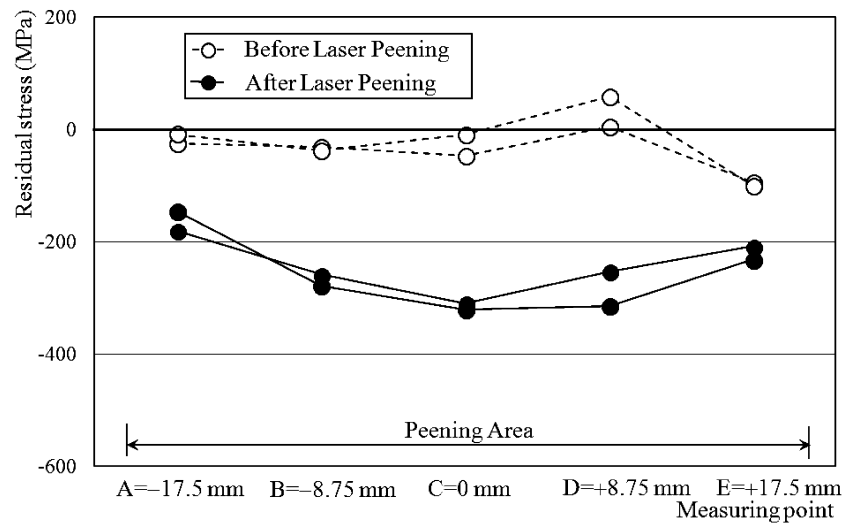

(a) A-B-C-D-E line

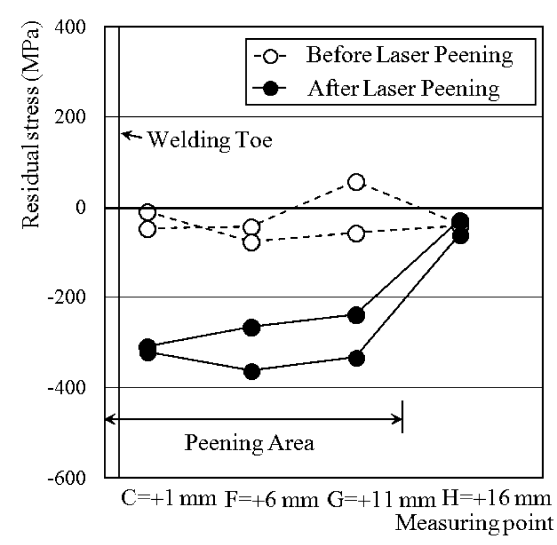

(b) C-F-G-H line

Fig. 3 Results of surface residual stress measurement $\left(\sigma_{x}\right)$ were measured. Figure 2 shows points $\mathrm{A}-\mathrm{H}$, the positions where residual stresses were measured. Note that the conditions for irradiation and other factors are the same as in the case of the base metal, and the direction of moving the stage at laser irradiation is indicated in $\mathrm{x}$ in Fig. 1. Figures 3 and 4 show the measurement results. $\sigma_{\mathrm{x}}$ is the residual stress component in the $\mathrm{x}$ direction (right angle to the rib), while $\sigma_{y}$ is the residual stress component in the $y$ direction (parallel to the rib). Before laser peening (indicated in $\bigcirc$ ), compressive residual stresses of around 100 $\mathrm{MPa}$ were measured at point $\mathrm{E}$, which is close to the edges of the specimen, while the stresses were measured to be almost $0 \mathrm{MPa}$ at other points. After laser peening (indicated by $)$, no change in residual stresses was seen at point $\mathrm{H}$ (the unpeened point), whereas large compressive residual stresses between -150 and $-450 \mathrm{MPa}$ were measured at the laser-peened points (A-G). Further, the closer a point is to the weld toe, the greater is the change in the residual stresses. In particular, point $\mathrm{C}$, which is closest to the toe where fatigue cracking is initiated, shows the largest change in residual stresses due to laser peening. It is therefore estimated that significant compressive residual stress is also generated near the boxing toe. These are the same results in the case of SM490.

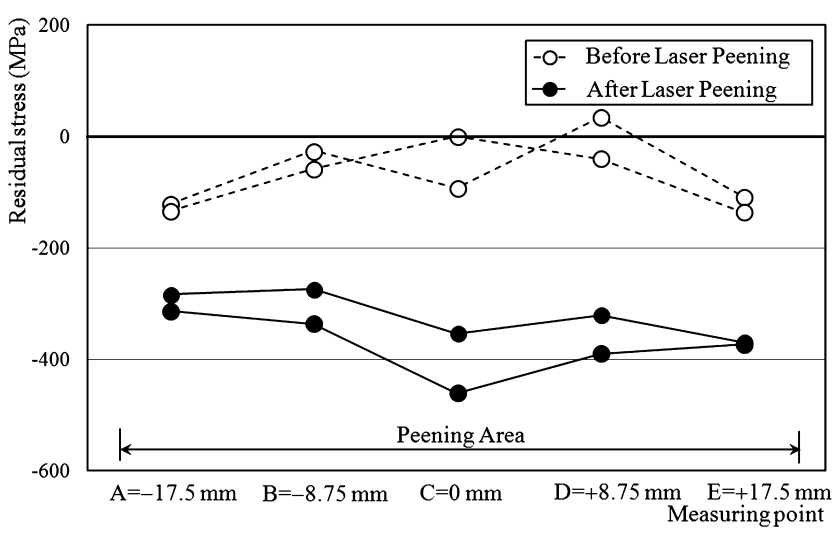

(a) A-B-C-D-E line

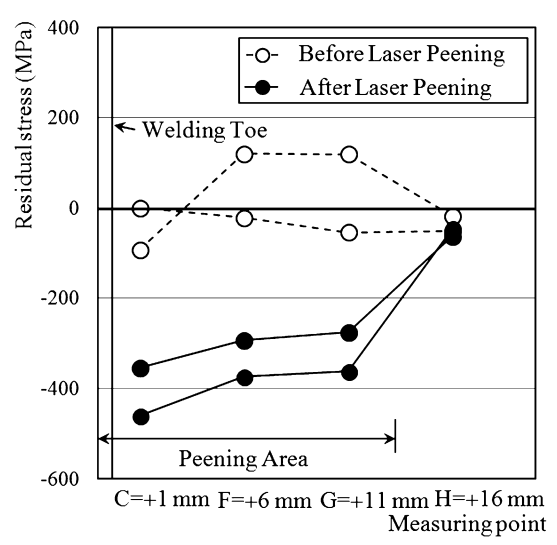

(b) C-F-G-H line

Fig. 4 Results of surface residual stress measurement $\left(\sigma_{\mathrm{y}}\right)$ 


\section{Distribution of residual stress in thickness direction}

The distribution of the Y-direction component $\left(\sigma_{\mathrm{y}}\right)$ of the residual stress at point $\mathrm{C}$ of laser-peened specimen in the thickness direction was estimated by repeating residual stress measurements using XRD and electrolytic polishing. Figure 5 shows the results of the measurement. The laser-peened specimen showed a large residual stress of over -500 MPa at a depth of around $0.2 \mathrm{~mm}$. Although the compressive residual stress gradually became smaller with depth beyond $0.4 \mathrm{~mm}$, a compressive residual stress of about -100 MPa remained even at a depth of 0.8 or $1.0 \mathrm{~mm}$. Consequently, it was shown that the toe surface of the butt-welded joint had a large compressive residual stress produced by laser peening up to a depth of about $0.8 \mathrm{~mm}$

\section{Effect of laser peening on fatigue life}

Fatigue tests were performed on laser-peened and unpeened specimens for a quantitative investigation to determine whether the fatigue life in the boxing toe of HT780 was prolonged by laser peening.

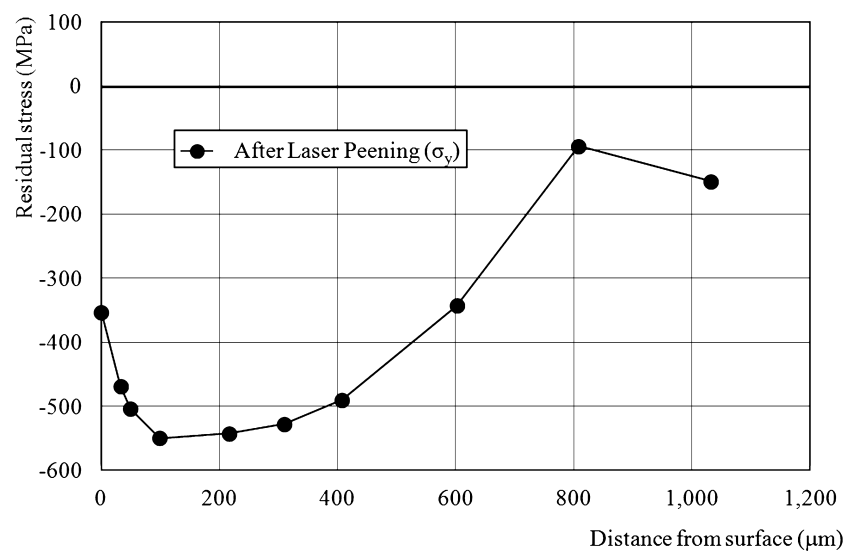

Fig. 5 Distribution of residual stress in the thickness direction $\left(\sigma_{\mathrm{y}}\right)$

\subsection{Experiment overview}

Using a $300 \mathrm{kN}$ uniaxial fatigue testing machine, fatigue tests were performed in constant stress ranges for the unpeened specimens (hereafter, called NP) and the laser-peened specimens (hereafter, called LP). The fatigue test was also performed for flat bar specimens (hereafter, called FB), which have no rib and box welding.

Figure 6 shows the shape and dimensions of the specimen in which an all-round fillet (leg length: $6 \mathrm{~mm}$ ) is welded to a $9 \mathrm{~mm}$ thick plate, along with a $6 \mathrm{~mm}$ thick steel plate used as a rib. The steel material and welding conditions are as mentioned in the section of residual stress in box toe. The position and the area of laser peening are shown in Figures 6 and 7. The laser peening conditions are the same as mentioned in the section of residual stress in base metal.

For the stress range to be loaded, there are two LPs each at 300, $350,400,450,500$, and $600 \mathrm{MPa}$, one at $550 \mathrm{MPa}$, making a total of 13 specimens; three NPs at 200 and $250 \mathrm{MPa}$, two each at 300 , $350,400,450,500,550$, and $600 \mathrm{MPa}$, making a total of 20 specimens; there are two FBs each at 350, 400, 450, 500, 550, and $600 \mathrm{MPa}$, making a total of 12 specimens. The stress ratio was 0 , and the censored limit was set at $10^{7}$ times.

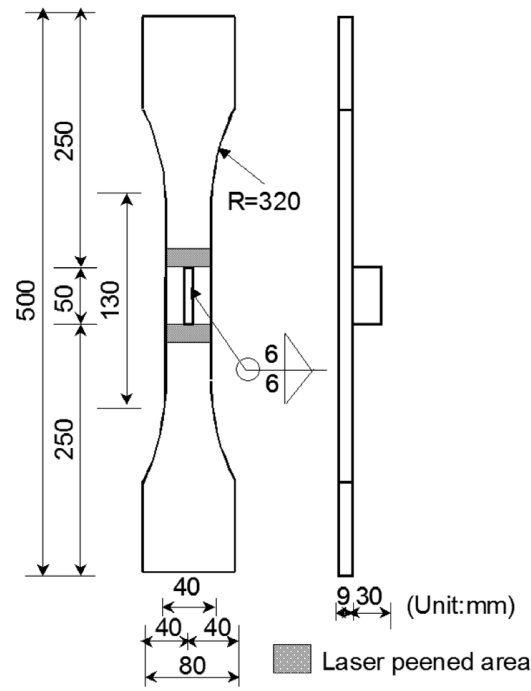

Fig. 6 Specimen for fatigue test
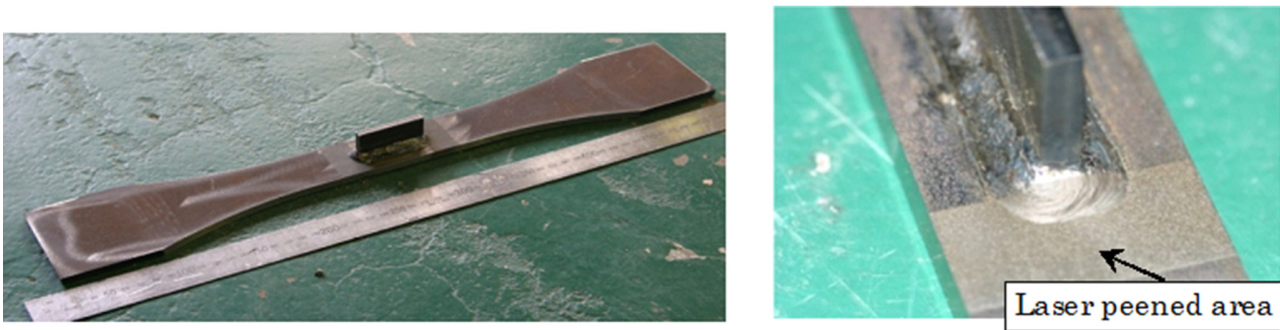

Fig. 7 Photograph of a box-welded rib specimen and its laser-peened area 


\subsection{Experiment results}

Figure 8 shows the S-N diagram obtained from the experiment. The arrows in the figure indicate that the number of fatigue reached censored limits without fatigue fracture.

Figure 9 shows photographs of the fracture surfaces. The mark in the figure represents the crack-initiation point, while the arrows show the direction in which cracking propagate. In the case of all NPs, crack initiation occurred at the boxing toe, where large stress concentration exists. In the case of LPs exceeding 450 $\mathrm{MPa}$, crack initiation occurred at the boxing toe. However, in the stress range between 350 and $400 \mathrm{MPa}$, cracks were initiated at unpeened back side of the boxing toe, where stress concentration does not exist, instead of at the laser-peened toe. In the case of all FBs, crack initiation occurred at border of parallel part and fillet part (named "(R)" in Fig. 8) of the base plate.

Three NPs in the $200 \mathrm{MPa}$ stress range and one out of three in the $250 \mathrm{MPa}$ range reached the censor limit; the remaining two NPs in the $250 \mathrm{MPa}$ range fractured at around $7 \times 10^{5}$ times and $26 \times 10^{5}$ times. This indicates that the fatigue limit of an unpeened specimen is $200 \mathrm{MPa}$.

On the other hand, two LPs reached the censor limit of $10^{7}$ times in the $300 \mathrm{MPa}$ stress range and fractured after around $42 \times$ $10^{5}$ times and $70 \times 10^{5}$ times in the $350 \mathrm{MPa}$ range. Therefore, the fatigue limit of the laser-peened specimen is $300 \mathrm{MPa}$. Further, cracks did not initiate from the toe but from the back side in the $350 \sim 400 \mathrm{MPa}$ stress range, illustrating the possibility that the fatigue limit of a laser-peened toe is $350 \mathrm{MPa}$, which is the fatigue limit of FBs.

Thus, the fatigue limit of the boxing toe in the high-strength steel increased from a stress range of $200 \mathrm{MPa}$ to at least 300 $\mathrm{MPa}$, i.e., by at least 1.5 times, as a result of laser peening.

Figure 10 shows a comparison between the fatigue lives of NPs and LPs in each stress range. The vertical axis represents how much times the fatigue life of each LP is longer when the average

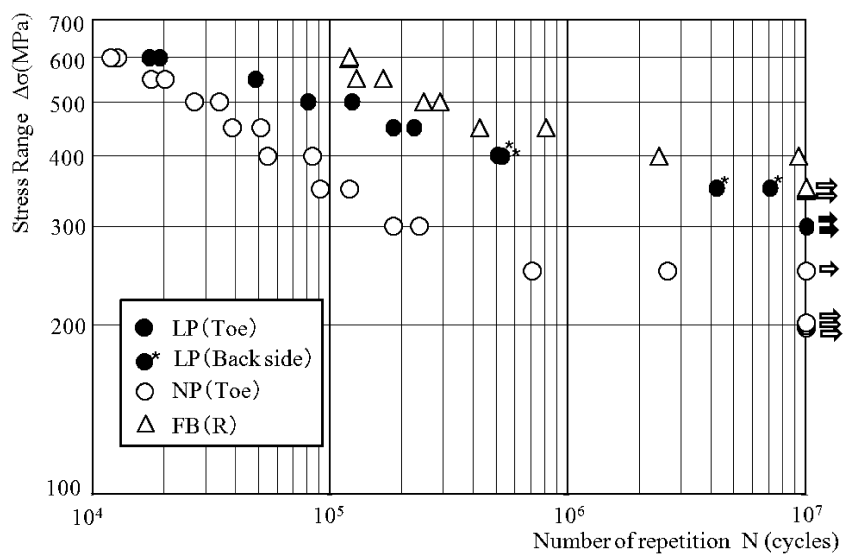

Fig. 8 S-N diagram fatigue life of two NPs in each stress range $\mathrm{NP}_{\mathrm{AVE}}$ was set to 1 . The arrows in the figure show that the fatigue life exceeded $10^{7}$ times. The fatigue life was $1 \sim 1.5$ times greater in the extremely high stress range of $600 \mathrm{MPa}$, indicating the reduced effect of laser peening. However, the fatigue life improved by more than 2.5 times in the 550 500 MPa range. In addition, the smaller the

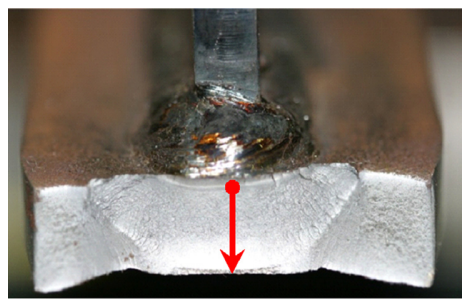

(a) NP (All stress ranges)

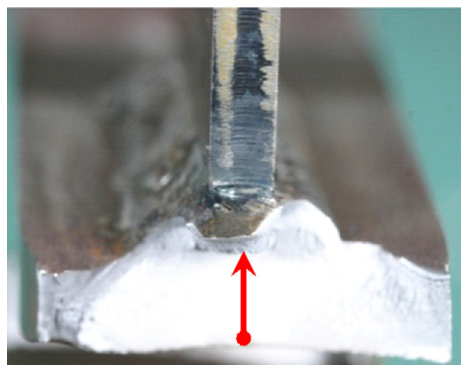

(b) $\operatorname{LP}(\Delta \sigma=350$ and $400 \mathrm{MPa})$

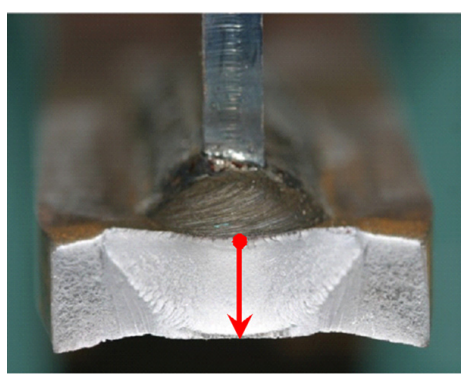

(c) $\mathrm{LP}(\Delta \sigma=450-600 \mathrm{MPa})$

Fig. 9 Fracture surface

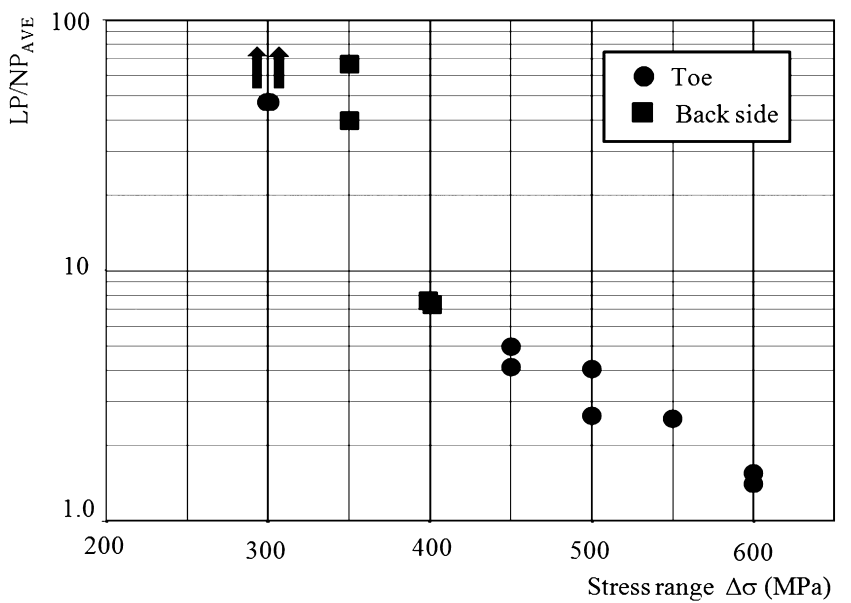

Fig. 10 Comparisons between NP and LP 
stress range is, the more significant is the improvement in the fatigue life, indicating that a fatigue life is at least 50 times greater in the $300 \mathrm{MPa}$ stress range.

These results confirmed that laser peening of the boxing toe in high-strength steel does not improve the fatigue life in the 600 $\mathrm{MPa}$ stress range while it prolonged the fatigue life by approximately $2.5 \sim 50$ times or more in the $300 \sim 550 \mathrm{MPa}$ stress range. This remarkably extended the fatigue life of the boxing toe. It was further revealed that the smaller the stress range, the greater was the improvement in the fatigue life.

\section{Conclusions}

This study targets $780 \mathrm{MPa}$ grade high-strength steel (HT780) in order to clarify whether laser peening generates compressive residual stresses on the surface of HT780, and whether such stresses would account for prolonged fatigue life in the welded zones of HT780. The results can be summarized as follows.

(1) Large compressive residual stresses were generated on the base metal surface of HT780 under the same peening conditions employed for $490 \mathrm{MPa}$ grade steel.

(2) Laser peening generated significant compressive residual stresses around the boxing toe of HT780, where fatigue cracking is usually initiated.

(3) The compressive residual stress at the boxing toe is produced up to a depth of about $0.8 \mathrm{~mm}$ caused by laser peening.

(4) In the laser-peened boxing toe specimen of HT780, crack initiation site varied depended on the stress range. For the stress ranges of 350 and $400 \mathrm{MPa}$, cracks were initiated from the back side of the toe where no stress concentration was observed.

(5) The fatigue limit of the boxing toe of HT780 was improved by at least 1.5 times as a result of laser peening.

(6) The smaller the stress range, the greater was the improvement of the fatigue life of boxing toe of HT780 by laser peening. The fatigue life in the stress range between 300 and $550 \mathrm{MPa}$ was prolonged by approximately $2.5 \sim 50$ times or more compared to the unpeened specimen.

Taking these points into consideration, it was concluded that laser peening of the boxing toe of the high-strength steel (HT780) generated large and deep compressive residual stress, which remarkably extended the fatigue life of this part.

\section{Acknowledgement}

This study was supported by JFE 21 st Century Foundation "FY 2008 University Research Aid (Technical Research)".

\section{Reference}

1) Y. Sano, N. Mukai, K. Okazaki and M. Obata: 'Residual stress improvement in metal surface by underwater laser irradiation', Nuclear Instruments and Methods in Physics Research Section B, 1997, 121, 432-436.

2) Y. Sano, T. Adachi, K. Akita, I. Altenberger, M. A. Cherif, B. Scholtes, K. Masaki, Y. Ochi and T. Inoue: 'Enhancement of surface property by low-energy laser peening without protective coating', Key Engineering Materials, 2007, 345-346, 1589-1592.

3) Y. Sano, M. Obata, T. Kubo, N. Mukai, M. Yoda, K. Masaki and Y. Ochi: 'Retardation of crack initiation and growth in austenitic stainless steels by laser peening without protective coating', Material Science and Engineering A, 2006, 417, 334-340.

4) K. Masaki, Y. Ochi, T. Matsumura and Y. Sano: 'Effects of laser peening treatment on high cycle fatigue properties of degassingprocessed cast aluminum alloy', Material Science and Engineering A, 2007, 468-470, 171-175.

5) I. Altenberger, Y. Sano, I. Nikitin and B. Scholtes: 'Fatigue behavior and residual stress state of laser shock peened materials at ambient and elevated temperatures', Proceedings of 9th International Fatigue Congress (FATIGUE 2006), Atlanta, 2006, Paper No. FT124.

6) C. Miki: 'Fatigue and fracture issues in civil structures', Sci. Technol. Weld. Joining, 2000, 5, 347-356

7) A. Joseph, P. Rai, and B. Raj: 'Non-destructive measurement of residual stresses in carbon steel weld joints', Sci. Technol. Weld. Joining, 1998, 3, 267-271

8) Y. Sakino, Y. Sano and Y.-C. Kim: 'Residual stress of steels for structure and filet weld zone after laser peening', Trans. JWRI, 2007, 36-2, 81-86.

9) Y. Sakino, Y. Sano and Y.-C. Kim: 'A preliminary study of applicability of laser peening to structural steels with various strength', Steel Construction Engineering, 2009, 18-69, 61-70.

10) Y. Sakino, Y. Sano and Y.-C. Kim: 'Fatigue lives of box-welded joints pretreated by laser peening', 62nd Annual Assembly of Int. Inst. Welding (IIW), Singapore, 2009, IIW Doc.XV-1316r1-09.

11) Y. Sakino, Y. Sano and Y.-C. Kim: 'Application of laser peening without coating on steel welded joints', International Journal of Structural Integrity, 2011, 2-3, 332-344.

12) Y. Sakino, Y. Sano, R. Sumiya and Y.-C. Kim: 'Major factor causing improvement in fatigue strength of butt-welded steel joints after laser peening without coating', Sci. Technol. Weld. Joining, 2012, 17- 5, 402-407. 